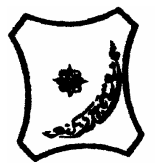

Bayero Journal of Pure and Applied Sciences, 6(1): 112 - 117

Received: November 2012

Accepted: April 2013

ISSN $2006-6996$

\title{
EFFECT OF STOCKING DENSITY ON PRODUCTION OF CLARIAS GARIEPINUS (TUEGELS) IN FLOATING BAMBOO CAGES AT KUBANNI RESERVIOR, ZARIA, NIGERIA
}

${ }^{1}$ Dasuki, A., ${ }^{2}$ Auta, J. and ${ }^{2}$ Oniye, S. J.

${ }^{1}$ Department of Fisheries and Aquacultural Technology, Federal University Dutsin-Ma, Katsina State, Nigeria

${ }^{2}$ Department of Biological Sciences, Ahmadu Bello University, Zaria, Kaduna State, Nigeria

*Correspondence author: awawudasuki@yahoo.co.uk,

\section{ABSTRACT}

The African Catfish (Clarias gariepinus, Teugels) were reared at three different stocking densities in bamboo-net cages to evaluate the effects of stocking density on growth, survival rate and food conversion ratio. Three hundred (300) fish with a total weight of $1.8 \mathrm{Kg}$ were stocked at 25,50 and $75 \mathrm{fish} / \mathrm{m}^{3}$ cage with a mean weight of $5.6 \pm 0.23 \mathrm{~g}, 5.9 \pm 0.23 \mathrm{~g}$ and $6.3 \pm 0.23 \mathrm{~g} / \mathrm{m}^{3}$ respectively. The growth trial lasted for 150 days (May 2009 to October 2009). Twenty percent (20\%) of the total biomass of the fish in each cage was weighed monthly and the bulk weights were calculated. Mortalities were recorded monthly. The final mean weights ( \pm S.E) of the fish stocked at densities of 25,50 and $75 \mathrm{fish} / \mathrm{m}^{3}$ cage were $828.0 \pm 1.83 \mathrm{~g}, 774.0 \pm 20.18 \mathrm{~g}$ and $693.0 \pm 34.20 \mathrm{~g}$. The corresponding mean values of Specific Growth Rate were 3.33, 3.25 and 3.43. Temperatures ranged between $24.5^{\circ} \mathrm{C}-32.6^{\circ} \mathrm{C}$ while salinity ranged between $24-95 \mathrm{ppm}$. The Feed Conversion Ratio (FCR) was 4.99, 4.73, and 3.43, and cumulative survival rates were calculated as $99.84,99.66$ and $99.50 \%$ respectively. The results revealed that stocking density had a significant $(P>0.05)$ effect on growth and survival rates of Clarias gariepinus. Fish held at the highest stocking density exhibited the lowest growth and survival rate. Cages with 50 fish/ $\mathrm{m}^{3}$ stocking density had the best production with total final weight $(38.67 \mathrm{Kg})$ and profit index (3.27) compared to other treatments (P>0.05).

Keywords: Stocking density, bamboo-net cages, profit index, survival, growth, Clarias gariepinus

\section{INTRODUCTION}

Fish can be cultured in one of four culture systemsponds, raceways, recirculation systems, or cages. Rearing of fish in enclosure (suspended cage in reservoirs) is a practice that is relatively new in the Northern part of Nigeria as compared to the Southern parts of Nigeria.

There is a considerable increase in the range of production values of fish catch and thus tropical water bodies offer better opportunities for extensive and semi-intensive cage and pen culture (Le Cren and Lowe-McConnell, 1980). Cage culture is an alternative means of aquaculture especially for land-less fish farmers and it is almost none existing in the NorthCentral part of the country. Nigeria is blessed with an abundance of scattered inland water mass of 12.5 million hectares comprising of lakes, reservoirs, ponds, dams, streams and rivers (Ita et al., 1985) part of which lies in the northern parts of the country and have the potential to serve in a multiuse capacity. Nigeria's domestic fish production is dominated by the small-scale artisanal farmers who could be encouraged to go into cage fish farming system utilising the vast available scattered inland water bodies which abounds in the Northern parts of the country and the arable lands used in other agricultural ventures. Cage culturing makes it possible to grow fish in bodies of water where draining and seining would be difficult or impossible.

The Catfish is very popular for fish farming in Nigeria (Faturoti, 2003). The African catfish Clarias gariepinus is known for its favourable food conversion, resistance to diseases, low technology farming system, excellent food meat quality (Fagbenro et al., 2003), possibility for high stocking density and can tolerate wide ranges of environmental conditions as well as being highly palatable (Eroudu et al., 1993; Nwandukwe, 1993).

\section{MATERIALS AND METHODS}

Six (6) floating bamboo net cages $\left(1 \mathrm{~m}^{3}\right)$ each made up of a wooden frame lined with net $(210 / 9,12.7 \mathrm{~mm}$ mesh size) and bamboo lattices walls with lockable lids were placed inside the Kubanni Reservoir (Ahmadu Bello University dam). The dam is approximately $122 \mathrm{~m}$ wide with a mean depth of $6 \mathrm{~m}$ in Samaru-Zaria. The cages were constructed according to Otubusin, (1985) specifications.

Each cage was stocked with Juveniles of $5.93 \pm 0.23 \mathrm{~g}$ average weight per fish replicated in a complete randomized design (CRD), randomly stocked at densities of 25,50 and 75 per cage corresponding to treatment I, II and III respectively. Each of the cages was replicated twice. Fish were fed with artificial floating feed containing $42 \%$ crude protein five days a week at $5 \%$ total biomass per treatment for the first sixty days, then $1 \%$ for the remaining culture days. Sampling of fish was carried out once a month, early in the morning between 7.00am and 9.00am using a scoop net (Otubusin and Olaitan, 2001). 
Twenty percent (20\%) of the stocked fish in each cage were sampled out and weighed using a Philip top loading balance (model SP). As the water level increased the position of the cages were adjusted to maintain a fairly regular $0.2 \mathrm{~m}$ free-board water level in all the cages. The fish were harvested after 150 days of culture period (May - October, 2009) by moving the cages to the shore, one after the other; the fish inside the cages were scoped out for mass weighing per cage and the total number of fish in each cage counted Osofero et. al., (2007). To determine the growth response of the fish, the following parameters were calculated:

\section{Mean Weight Gain (g) (MWG)}

$\mathrm{MWG}=\mathrm{Wt}_{2}-\mathrm{Wt}_{1}$

Where $\mathrm{Wt}_{1}=$ initial mean weight of fish at time $\mathrm{T}_{1}$

$\mathrm{Wt}_{2}=$ final mean weight of fish at time $\mathrm{T}_{2}$

Feed Conversion Ratio (g) (FCR) (Hepher, 1988)

FCR $=$ weight of feed given $(\mathrm{g})$

Fish weight gain (g)

Relative Growth Rate (RGR) (Wannigamma et al., 1985)

$\operatorname{RGR}(\%)=\left(W_{f}-W_{i}\right) \times 100$

$\mathrm{W}_{\mathrm{i}}$

$W_{f}=$ final average weight at the end of the experiment

$\mathrm{W}_{\mathrm{i}}=$ initial average weight at the beginning of the experiment

Protein Efficiency Ratio (PER) (Wilson, 1989)

PER $=$ fish Weight Gain $(\mathrm{g})$

Protein intake $(\mathrm{g})$

Where;

Protein intake $=\%$ protein in feed $\mathrm{x}$ total diet consumed

100

Specific Growth Rate (SGR) (Hepher, 1988)

$S G R=100\left(\log _{e} W f-\log _{e} W_{i}\right)$

Time (days)

$\mathrm{W}_{\mathrm{f}}=$ final average weight at the end of the experiment

$W_{i}=$ initial average weight at the beginning of the experiment

$\log _{\mathrm{e}}=$ Natural Logarithm reading

Time $=$ Number of days for the experiment

Survival rate $(\%)$

Survival Rate $(\%)=$ Number of fish that survived $\mathrm{x} 10$

Total number of fish stocked

Production $\left(\mathrm{Kg} / \mathrm{m}^{3}\right)$ (Osofero et al., 2007)

Production $\left(\mathrm{Kg} / \mathrm{m}^{3}\right)=$ Total weight of fish cropped @ $\$ 500.00 / \mathrm{Kg}$

Cost of feed + Cost of juveniles \& cage

\section{Production Index (Mohanty, 2004)}

$P I=\underline{\text { survival rate } x \text { final weight }(g) \text { - initial weight }(g)}$

Duration of rearing period (days)

Physicochemical analysis of water was measured weekly during the duration of the study. Water temperature, hydrogen ion concentration $(\mathrm{pH})$, electrical conductivity and total dissolved solids were determined using HANNA instruments: HI-98129 and $\mathrm{HI}-987130$ while, dissolved oxygen (DO) was analysed using dissolved oxygen test kit HI-3810 following the manufacturer's instructions. Water depth was measured using a calibrated bamboo pole.

Data were analysed by One-Way Analysis of Variance (ANOVA) (Snedecor and Cochran, 1982) and difference between means was examined using
Duncan's Multiple Range Test (Duncan, 1955). Correlation coefficient was used to determine the relationship between weight gain and food conversion ratio, stocking density and growth, weight gain and protein efficiency ratio and production and food conversion ratio.

\section{RESULTS}

Water temperature (WTP) (Table 1 ) in the cages was highest in May $\left(32.6^{\circ} \mathrm{C}\right)$ and lowest $\left(24.5^{\circ} \mathrm{C}\right)$ in September while, the hydrogen ion concentration ranged from $6.8-8.5$. 
The highest $\mathrm{pH}$ of 8.5 was recorded in May and the lowest $\mathrm{pH}$ of 6.8 was recorded in October. Dissolved oxygen (DO) during the culture period ranged from $4.6 \mathrm{mg} / \mathrm{l}$ to $12 \mathrm{mg} / \mathrm{l}$. Dissolved oxygen (DO) increased from May to October, and the highest $(12 \mathrm{mg} / \mathrm{l})$ was recorded in September and the lowest DO $(4.6 \mathrm{mg} / \mathrm{l})$ was obtained in June. The highest electrical conductivity (EC) $(190 \mu \mathrm{s} / \mathrm{cm})$ was recorded in May and lowest $(45 \mu \mathrm{s} / \mathrm{cm})$ in August while the mean monthly total dissolved solids (TDS) ranged between 24 - 95ppm.

Table1: Mean of some Physicochemical Parameters of Water in all the Treatments for the culture Period

\begin{tabular}{|c|c|c|c|c|c|}
\hline MONTHS (2009) & $\begin{array}{l}\text { PARAMETERS } \\
\text { EC ( } \mu \mathrm{s} / \mathrm{cm})\end{array}$ & pH & $\begin{array}{c}\text { DO } \\
(\mathrm{mg} / \mathrm{I})\end{array}$ & WTP $\left({ }^{\circ} \mathrm{C}\right)$ & TDS (ppm) \\
\hline MAY & $190^{\mathrm{a}}$ & $8.5^{\mathrm{a}}$ & $4.8^{b}$ & $32.6^{\mathrm{a}}$ & $95^{\mathrm{a}}$ \\
\hline JUNE & $103^{b}$ & $8.1^{a}$ & $4.6^{\mathrm{b}}$ & $30.6^{\mathrm{a}}$ & $71^{b}$ \\
\hline JULY & $93^{\mathrm{b}}$ & $7.2^{\mathrm{b}}$ & $5.0^{\mathrm{b}}$ & $26.4^{b}$ & $48^{c}$ \\
\hline AUGUST & $45^{c}$ & $7.7^{\mathrm{b}}$ & $8.6^{\mathrm{ab}}$ & $27.0^{b}$ & $24^{c}$ \\
\hline SEPTEMBER & $50^{c}$ & $7.2^{\mathrm{b}}$ & $12.0^{\mathrm{a}}$ & $24.5^{b}$ & $27^{c}$ \\
\hline OCTOBER & $50^{c}$ & $6.8^{\mathrm{b}}$ & $10.0^{\mathrm{a}}$ & $28.0^{b}$ & $30^{c}$ \\
\hline S.E.M & 22.65 & 0.26 & 1.29 & 1.21 & 11.65 \\
\hline
\end{tabular}

Values with different letter superscripts in the same column are significantly different at $(P>0.05)$.

S.E.M = standard Error of Mean; $\quad$ DO = Dissolved Oxygen; WTP= Water Temperaure; $\mathrm{pH}=$ Hydrogen Ion concentration; $\quad$ TDS = Total Dissolved Solids; $\quad$ EC=Eectrical Conductivity

The mean initial weight (IWT) (Table 2) in all the treatments was $5.93 \pm 0.23 \mathrm{~g}$; range was between 5.4 $7.0 \mathrm{~g}$ while the mean final weight (FWT) ranged from $679 \mathrm{~g}-858 \mathrm{~g}$. The daily weight gain (DWG) showed an inverse relationship as the stocking density increased.
Treatment I (25 juveniles /cage) had the highest final mean weight of $828 \mathrm{~g} /$ fish, then $774 \mathrm{~g} /$ fish in treatment II (50 juveniles /cage) and the least $693 \mathrm{~g} /$ fish was recorded in treatment III (75 juveniles /cage)(Table 2). 
Table 2: Summary of the Mean Growth Performance at Different Stocking Densities of Clarias gariepinus cultured in Bamboo - Net Cages

\begin{tabular}{|c|c|c|c|c|c|c|c|c|c|c|c|c|c|c|c|}
\hline TRT & (SD) & I WT & ( Kg) & F WT & $(\mathbf{K g})$ & $\begin{array}{l}\text { WTG } \\
\text { (Kg) }\end{array}$ & RGR & $(\%)$ & $\begin{array}{l}\text { SGR\$ } \\
\text { (\% /day) }\end{array}$ & FCR & $\begin{array}{l}\text { SURV } \\
(\%)\end{array}$ & $\begin{array}{l}\text { DWG } \\
\text { (Kg/day) }\end{array}$ & $\begin{array}{l}\text { PRO } \\
\text { (Kg/cage) }\end{array}$ & $\begin{array}{l}\text { Water } \\
\text { depth (m) }\end{array}$ & PER \\
\hline I & (25) & $\begin{array}{l}0.14 \\
(5.7 \mathrm{~g} / \mathrm{fish})\end{array}$ & & $\begin{array}{l}20.69 \\
(828 \mathrm{~g} / \text { fish })\end{array}$ & & 20.55 & 14.71 & & 3.33 & 4.73 & 99.84 & 0.14 & 25.86 & 0.5 & 4.79 \\
\hline II & (50) & $\begin{array}{l}0.3 \\
(6.0 \mathrm{~g} / \mathrm{fish})\end{array}$ & & $\begin{array}{l}38.67 \\
\text { (774g/fish) }\end{array}$ & & 38.37 & 12.95 & & 3.25 & 4.99 & 99.67 & 0.26 & 48.34 & 0.5 & 4.80 \\
\hline III & (75) & $\begin{array}{l}0.47 \\
(6.3 \mathrm{~g} / \text { fish })\end{array}$ & & $\begin{array}{l}51.97 \\
(693 \mathrm{~g} / \text { fish) }\end{array}$ & & 51.5 & 11.11 & & 3.14 & 3.43 & 99.5 & 0.35 & 64.97 & 0.5 & 4.48 \\
\hline S.E.M & & 0.1 & & 9.06 & & 8.97 & 1.04 & & 0.06 & 0.48 & 0.1 & 0.06 & 11.33 & 0 & 0.11 \\
\hline
\end{tabular}

TRT $=$ Treatment, SD = Stocking Density, PER = Protein Efficiency Ratio, IWT = Initial Weight, FWT = Final Weight, DWG = Daily Weight Gain, WTG = Weight Gain, SGR = Specific Growth Rate, FCR = Feed Conversion Ratio, S.E.M = Standard Error of Mean, RGR = Relative Growth Rate, PRO= Production

Feed conversion ratio (FCR) in this study showed that treatment III had the best conversion ratio (3.43) while treatment II had the lowest (4.99). Daily weight gain (DWG) was observed to be low in all treatment but, gradually increased during the course of the experiment. Relative Growth Rate (RGR) in all the treatments was high Treatment I (14.71), followed by treatment II (12.95) and the least was in treatment III (11.11). There was significant difference ( $P \square 0.05)$ in relative growth rate in all the treatments. The Specific Growth Rate decreased with increase in stocking density

with the highest value being $3.33 \%$ in treatment I, followed by $3.25 \%$ in treatment II and the least $3.14 \%$ was in treatment III (Table 2). There was no significant difference $(P<0.05)$ in the daily weight gain in all treatments.

There was a high correlation $(r=0.01)$ between the Daily Weight Gain and the Protein Efficiency Ratio, Feed Conversion Ratio and Mean Weight (Table 3). The cost of production (Table 4) recorded shows that there was a marginal decrease in terms of profit from 7,969.95 to $\$ 5,185.80$ as the stocking density increased.

\section{Table 3. Correlation Matrix of Growth Parameters of Clarias gariepinus during the culture period}

\begin{tabular}{|c|c|c|c|c|c|c|c|c|c|c|}
\hline & $I W T$ & $F W T$ & WTG & $R G R$ & $S G R$ & $F C R$ & SURV & $D W G$ & PRO & PER \\
\hline IWT & 1 & & & & & & & & & \\
\hline FWT & $0.99463 * *$ & 1 & & & & & & & & \\
\hline WTG & $0.99452 * *$ & 0.99999** & 1 & & & & & & & \\
\hline RGR & $-0.99999 * *$ & $-0.9951^{* *}$ & $-0.99499 * *$ & 1 & & & & & & \\
\hline SGR & $-0.99731 * *$ & $-0.98436 * *$ & $-0.98417 * *$ & $0.99695 * *$ & 1 & & & & & \\
\hline FCR & $-0.78859 * *$ & $-0.72073 * *$ & $-0.71997 * *$ & $0.78571 * *$ & $0.83157 * *$ & 1 & & & & \\
\hline SURV & $-0.99985 * *$ & $-0.99629 * *$ & $-0.99619 * *$ & $0.99992 * *$ & $0.99587 * *$ & $0.77771 * *$ & 1 & & & \\
\hline DWG & $0.99503 * *$ & 0.99999** & 0.99999** & $-0.99548 * *$ & $-0.98504 * *$ & $-0.72341 * *$ & $-0.99662 * *$ & 1 & & \\
\hline PRO & $0.99463 * *$ & $1.00000 * *$ & 0.99999** & $-0.99511 * *$ & $-0.98437 * *$ & $-0.72074 * *$ & $-0.99629 * *$ & 0.99999** & 1 & \\
\hline PER & $-0.86099 * *$ & $-0.80373 * *$ & $-0.80308 * *$ & $0.85860 * *$ & $0.89598^{* *}$ & $0.99173 * *$ & $0.85196 * *$ & $-0.80603 * *$ & $-0.80375^{* *}$ & 1 \\
\hline
\end{tabular}

Initial Weight; FWT = Final Weight; SURV=Survival; DWG=DailyWeightGaim; $* *$ Significant at $\mathrm{P} \square 0.01$ 
Table 4. Summary of Cost Benefit Analysis of Clarias gariepinus during the culture period.

$\begin{array}{ll} & \text { I } \\ \text { Production period (days) } & 150 \\ \text { Stocking Density (per cage) } & 25 \\ \text { Net production (Kg/cage/150days) } & 25.86 \\ \text { Value of Fish @ } \$ 500.00 / \mathrm{Kg} & 12,930.00 \\ \text { Feed Input (Kg) } & 10.22 \\ \text { Cost of feed/ Kg (\#) } & 313 \\ \text { Cost of Feed used ( }) & 3,198.86 \\ \text { Cost of Fingerlings (\#) } & 500 \\ \text { Cost of cage (\#) } & 416.70 \\ \text { Total cost of Production (\#) } & 4,115.56 \\ \text { Gross Profit (\#) } & 8,814.44 \\ \text { Profit Index } & 3.14^{\mathrm{b}} \\ \text { Values with different superscripts in the same row are sign }\end{array}$

\section{DISCUSSION}

Stocking density is one of the main factors determining fish growth (Engle and Valderrama, 2001; Rahman et al., 2005) and the final biomass harvested (Boujard et al., 2002). Identifying the optimum stocking density for a species is a critical factor not only for designing an efficient culture system (Leatherland and Cho, 1985), but also for optimum husbandry practices. Controlling the fish size and production are the two important tasks to meet the market demands. The high survival rate recorded in all the treatments could be attributed partially to the physico-chemical parameters of the water body and also due to the good health condition of the fish. The survival of Clarias gariepinus ranged between 99.50 $99.84 \%$ which was comparable to similar work done by Otubusin (2000) and Osofero et al. (2007) with a range of 98.5 - 99.5\%. Low mortality (2.3\%) recorded in this study is an indication of proper handling of experimental procedures. The growth rate of $3.2 \mathrm{~g} /$ day observed in this study was similar to the findings of Otubusin (1997) who reported $3.28 \mathrm{~g} /$ day for Clarias gariepinus in a polyculture study in netcages but lower than $4.2 \mathrm{~g} /$ day reported for Clarias gariepinus in net-cages by Otubusin and Olaitan (2001) and 7.3g/day reported by Otubusin et al. (2004) which, could be due to the feeding pattern adopted (feeding ad-libitum and use of $45 \%$ crude protein feed), the higher average weight of stocked fish and higher stocking densities used during the experiment; but higher when compared with other culturing system like concrete tank monoculture for hybrid catfish; $2.6 \mathrm{~g} /$ day as reported by Salami et al. (1993) and $0.012 \mathrm{~g} /$ day by Egwui (1986) in home stead concrete tanks. Marginal incremental economic benefit decreased from $\$ 7,969.95$ to $\$ 5,185.80$ which could be as a result of increase in stocking density and can be attributed to the cost of production from the value of cropped fish. The growth and mortality of Clarias gariepinus cultured at various stocking densities were not initially affected by density but, the overall harvest productions in terms of final weight and size were directly related to the stocking density. As the stocking density increased, the weight gain decreased; this depicts an inverse relationship as was observed in similar works by Otubusin and Olaitan

\section{TREATMENTS}

$\begin{array}{ll}\text { II } & \text { III } \\ 150 & 150 \\ 50 & 75 \\ 48.34 & 64.97 \\ 24,170.00 & 32,485.00 \\ 19.07 & 27.47 \\ 313 & 313 \\ 5,968.91 & 8,598.11 \\ 1,000 & 1,250 \\ 416.70 & 416.70 \\ 7,385.61 & 10,514.81 \\ 16,784.39 & 21,970.19 \\ 3.27^{\mathrm{a}} & 3.09^{\mathrm{c}}\end{array}$

(2001). Growth is a manifestation of the net outcome of energy gains and losses within an environment. Weight gain is one of the important indices for measuring growth which was obvious among the different treatments. This study shows that at higher stocking density fish expend more energy due to aggressive feeding than converting it to flesh. The ability of Clarias gariepinus to utilize feed nutrients at maximum biochemical efficiency and the feeding rate of $1 \%$ used in this study could be attributed to the high productivity of Kubanni reservoir (Adakole et al., 2003).

The high production obtained in all treatments in this study could be linked to the favourable physicochemical condition of the water, maximum utilization of feeds and design of the cages. Optimum water growth conditions for Clarias gariepinus include a temperature range of $25^{\circ} \mathrm{C}-30^{\circ} \mathrm{C}$ (Auta, 1993); Dissolved Oxygen of $5 \mathrm{mg} / \mathrm{l}$ (Adakole, 2000) and $\mathrm{pH}$ values of between 6.5 - 9.0 (Adeniji, 1986; Auta,1993) which, are similar to the values obtained in this work. It could also be attributed to the high $(42 \%)$ crude protein content of the feed. The Profit Index (Table 5) for all treatments was significantly different at $(P>0.05)$ and this is reflected in the feed conversion (FCR) and specific growth rates (SGR) recorded in all the treatments. It is therefore apparent that biological and economic benefit will be achieved in intensive cage culture of Clarias gariepinus juvenile when stocked at $50 / \mathrm{m}^{3}$. The higher profit index in treatment II over the other treatments shows that the 50 fish per $1 \mathrm{~m}^{3}$ cage may be economically viable in terms of final weight and size than $75 / \mathrm{m}^{3}$ cage for Clarias gariepinus when fed with a diet containing $42 \%$ crude protein.

\section{CONCLUSION/ RECOMMENDATION}

The result obtained in this experiment indicates that Stocking Density of 50 fish per $1 \mathrm{~m}^{3}$ cage is better than at 25 or 75 fish per $1 \mathrm{~m}^{3}$ cage.

It can be recommended therefore that for optimum productivity, density of caged fish should not exceed 50 fish per $1 \mathrm{~m}^{3}$ cage. However, further research can be carried out using other species or local feed to determine the stocking density of Clarias gariepinus. 


\section{REFRENCES}

Adakole, J. A. (2000): The effects of Diuretic, Agricultural and industrial effluents on the water quality and Biota of Bindare stream, Zaria-Nigeria. Unpublished Ph.D Thesis. Ahmadu Bello University Zaria Nigeria 256pp.

Adakole, J. A., Mbah, C. E. and Dallah, M. A. (2003): Physicochemical Limnology of Lake Kubanni Zaria Nigeria. In: Towards the Millennium Development Goals, $29^{\text {th }}$ WEDC International Conference Abuja Nigeria.

Adeniji, H. A. (1986): Some Limnological precautions for fish farmers. Kainji Lake Research Institute Annual Report. pp $54-56$.

Auta, J. (1993): Water Quality Management in Fish Ponds. Proceedings of National Workshop on Fisheries Extension Delivery. 2P.

Boujard, T., Labbé, L. and Aupérin, B. (2002): Feeding behaviour, energy expenditure and growth of rainbow in relation to stocking density and food accessibility. Aquaculture Research 33: 12331242.

Duncan, D.B. (1955): Multiple Range and Multiple (F) test. Biometrics, 11: 1-12.

Egwui, P. C. (1986): Yields of the African catfish Clarias gariepinus (Burchell), from a low input, homestead, concrete pond. Aquaculture, 55: 87-91.

Engle, C. R. and Valderrama, D. (2001): Effect of stocking density on production characteristics, coasts, and risk of producing fingerlings channel catfish. North

American Journal of Aquaculture 63: 201-207.

Eroudo, E. S., Nnubai, C. And Nwaduke, F. O. (1993): Haematological studies on four catfish species raised in water pounds, In: Nigerian Journal of Applied Ichthyology, 9:250 - 256.

Fagbenro, O. A. Adeparusi, E. O. and Fapounda, O. O. (2003): Feedstuffs and dietary substitution for the farmed fish in Nigeria. In; National Workshop on Fish Feed Development and Feeding Practices in Aquaculture organized by FISON in collaboration with NFFR and FAO Special programme on Food Security (SPFS). A. A. Eyo (Ed), New Bussa, $15^{\text {th }}-19^{\text {th }}$ Sept. Pp 60 -72 .

Faturoti, E. O. (2003): Commercial Fish Feed development and Aquaculture. In: National Workshop on Fish Feed Development and Feeding Practices in Aquaculture. A. A. Eyo (Ed). FISON/NIFFR/FAO-NSPFS.88 - 94pp.

Hepher, B. (1988): Nutrition of Pond Fishes. Cambridge University Press. 388pp.

Ita, E. O., Sado, E. K., Balogun, J. K., Pandogari, A. and Ibitoye, B. (1985): Inventory survey of Nigeria with special reference to ponds, lakes, Reserviors and major Rivers. KLRI Technical Report Series. NO. 14, 51pp.

Leatherland, J. F. and Cho, C. Y. (1985): Effect of rearing density on thyroid and inter- renal gland activity and plasma and hepatic metabolite levels in rainbow trout, Salmo gairdneri Richardson. Journal of Fish Biology, 27: 583-592.

Le Cren, E. D. and Lowe-McConnell, R. H. (1980): The functioning of freshwater ecosystems. Cambridge, England. Cambridge University
Press, International Programme. 22: 588p.

Biological

Mohanty, R. K. (2004): Density-dependent growth performance of Indian major carps in rain water reservoirs. Journal of Applied Ichthyology 20: 123-127.

Nwadukwe, F. O. (1993): Including Oocytes Maturation, Ovulation and Spawning in the African Catfish Heterobranchus longifilis using frog pituitary extract. Aquaculture fish management 24: pp 625- 630.

Osofero, S. A., Otubusin, S.O. and Daramola, J. A. (2007): Effect of Stocking density on Tilapia (Oreochromis niloticus, Linnaeus 1757). Growth and Survival in Bamboo- Net Cages Trial. In: Journal of Fisheries International 2 (2): $182-185 \mathrm{pp}$.

Otubusin, S.O. (1985): Preliminary Studies on Bamboo Floating Cage and Net enclosure Fish Culture in Kanji Lake Basin. Proc of the $4^{\text {th }}$ Annual Conference of the Fisheries Society of Nigeria, African Regional Aquaculture Center (ARAC), Aluu, Port-Harcourt, Nigeria. $26^{\text {th }}-29^{\text {th }}$ Nov. 1985. Pp 113-128.

Otubusin, S.O. (1997): Cage culturability of some commercially important fish species in Lake Kainji, Nigeria. Tropical freshwater Biology. 6:41-47.

Otubusin, S.O. (2000): The effects of different feedstuff on tilapia, Oreochromis niloticus fry in floating net- hapa, Nigerian Journal of Science 34 (4): $377-379$.

Otubusin, S.O. and Olaitan, O. O. (2001): The production of cat fish (Clarias gariepinus) floating bamboo net-cage system in Nigeria. ASSET Series A, 1 (1):77-82.

Otubusin, S.O., Olaofe, O. O. and Agbebi, O. T. (2004): High yields and growth of catfish (Clarias gariepinus) in floating bamboo net cage system in Nigeria. Nigeria Journal of Science. Sci. Ass. of Nig 12p.

Rahman, M. A., Mazid, M A., Rahman, M. R., Khan, M. N., Hossain, M. A. and Hussain, M. G. (2005): Effect of stocking density on survival and growth of critically endangered mashseer, Tor putitora (Hamilton), in nursery ponds. Aquaculture 249: 275-284.

Salami, A. A., Fagbenro, O. A. and Sydenham, D. H. J. (1993): The production and growth of clarrid catfish hybrids in concrete tanks. The Isreal journal of Bamidgeh 45(1): 18-25.

Snedecor, G.W. and Cochran, W.G. (1982): Statistical Methods. $6^{\text {th }}$ Edition, Iowa State University Press, Ames, IA, USA, PP.593.

Wannigama, D. N., Weerakon, D.E. M. and Muthukumarana, G. (1985): Cage culture of S. niloticus in Sri Lanka: Effect of Stocking Density and Dietary Crude Protein levels on Growth. In: Finish Nutrition in Asia. International Development Research Center Ottawa, Canada.

Wilson, R. P. (1989): Amino acid and protein requirement of fish. In: nutition and fish. Academic press London. feeding in 